\title{
МЕТАФОРИ ОТ ОБЛАСТТА НА ХРАНЕНЕТО В БЪЛГАРСКИЯ ЕЗИК
}

\author{
Dimka SAVOVA \\ Uniwersytet Sofijski im. św. Klemensa Ochrydzkiego
}

\begin{abstract}
FOOD METAPHORS IN THE BULGARIAN LANGUAGE. The article aims at analysing the lexical field of food as a source of metaphorical transfer. The lexemes with possible metaphorical usage are classified according to one main criterion: the motivational feature of the metaphorization. In the case of two subgroups, the latter is supplemented by two auxiliary criteria. The article draws conclusions about the associative thinking of native Bulgarian speakers with respect to their life experience in the field under consideration.
\end{abstract}

Keywords: conceptual metaphor, lexical metaphor, motivational feature, primary and secondary nominate

В тази статия изхождам от застъпеното в когнитивистиката мнение, че метафорите като езикови изрази могат да бъдат породени от два вида мотивация: 1) от въплътен опит (embodiment), откриващ аналогия между две понятийни области (домени), срв. аналогията теория ↔ сграда, понятийната метафора теорията е сграда и многобройните метафорични езикови изрази, свързани с нея (наричам ги традиционно лексикални метафори): Имаме като основа солидна аргументация; Ако не подпреш своите аргументи със солидни факти, цялата постройка ще се разпадне'; 2) от подобие на определена черта, обединяващо два обекта от различни сфери в качеството си на мотивационен признак за метафоризация, срв.: Ахил беше лъв $\rightarrow$ обединяваща черта е смелостта (вж. Kovecses 2011: 181). Това мнение не противопоставя, а позволява да се прилагат успоредно двете перспективи, през които обикновено в литературата се гледа на езиковата метафора: когнитивната (във връзка с понятийната метафора) и традиционната (във връзка с лексикалната метафора). Известно е, че

1 Вж. Kovecses 2011: 188 - преводът на приведените примери е мой, Д.С. 
понякога примери, породени от някаква понятийна метафора, като трансформирания пример, цитиран по-горе: Трябва да подпреш аргументите си с факти, породен от понятийната метафора теорията е сграда, могат да се разглеждат и от двете перспективи. В нашия случай можем да смятаме: 1) в духа на когнитивистичната перспектива, че аргументите се възприемат като част от постройка, която трябва да се подпре, за да не се събори; 2) от друга страна - в духа на традиционната перспектива можем да разглеждаме като лексикална метафора само глагола да подпра, който в контекста на съществителното аргументи променя своето буквално значение в преносно (срв. използването на такава двойна перспектива напр. при Райна Драгичевич: Dragichevich 2010).

В статията поставям следната задача: в опита на даден колектив, отразен в езика му, да се открои и анализира една определена област, използвана като изходна (изворна) за извършване на метафоризация; да се класифицират според мотивационния признак събраните метафори; да се направят наблюдения върху очертаващите се в резултат на метафоризацията семантични типове вторични номинати и на базата на всичко това да бъдат предложени обосновани заключения за асоциативното мислене на този езиков колектив. В случая се опитвам да направя изводи за това как носителят на българския език възприема и отразява в езика си своя опит, придобит в областта на храненето르, и с кои други сфери от колективния си опит го свързва, като открива сходства и аналогии, закрепени в езикови метафори. Спирам се върху сферата на храненето, защото ми се струва, че тя не е специално проучвана в литературата. Като цяло, в литературата за българския език не ми е известно да е прилаган и самият модел на изследване с посока от изходната, изворната област (за руския език като пример бих посочила изследване на метафорите с органичен произход: зооморфни, фитоморфни и атропоморфни, в руския политически дискурс, Vershinina 2002). В своето изследване за системността в лексикалната многозначност Е. Пернишка (Pernishka 1993) разглежда само съществителните, като се опира върху два критерия: мотивационния признак и най-общите значения на получените вторични номинати (ономасиологични бази). С. Колковска в общи линии следва същата методология при изследването на новите метафорични значения: при съществителните, прилагателните и при глаголите (Kolkovska 2012, 2013). Св. Пачева-Карабова (Pacheva-Karabova 2005) и Ж. Станчева (Stancheva 2015) разглеждат процеса на метафоризация при образуване на медицински термини, но в посока, обратна на приетата тук - класифицират

2 Понятийната структурна метафора на Лейкъф и Джонсън Мислите са храна, анализирана в Lakoff \& Johnson 2010, обхваща само част от тази област. 
сферите, от които чрез метафоризация се попълва с термини целевата област - названията на болести.

Сферата на дейностите, свързани с храненето, т.е. с ядене и пиене, е важна за човека и затова може да се предположи, че лексиката от съответната тематична област е развила в една по-изразена степен метафоричната си употреба. В статията изследвам тази употреба, като ексцерпирам материала си от последното, четвърто издание на Българския тълковен речник на Л. Андрейчин и колектив (БТР 2018). Освен посочените в речника данни за преносна (отделям само метафоричната) употреба отчитам и значения, продуцирани от моя езиков усет. От всички отделени лексеми, свързани със сферата на храненето, които общо надвишават 50о, с метафорична употреба съм отбелязала 160 позиции, т.е. приблизително една трета от наличните лексикални единици. В техния състав влизат съществителни, прилагателни, глаголи, наречия.

В разглежданата сфера като тематични могат да се откроят следните подгрупи: отделни произведени от човека разновидности на храната (не включвам към тях названията на плодовете и зеленчуците, които влизат в друга тематична област, макар че принадлежат към списъка на храните и напитките); действия, свързани с поемането на тези храни и напитки; дейности, свързани с приготвянето им за консумация; усещанията, свързани с вкусовите рецептори, и съответните качества на храната и напитките; явления, съпровождащи или настъпващи в резултат от храненето и пиенето.

В ексцерпирания материал не включвам случаите на синонимия между книжовната лексема и някакъв неин некнижовен вариант. А такива са случаите, когато имаме жаргонни варианти на съответните лексеми (ям - кльопам; ядене - кльопачка). Няма да разглеждам в тази статия и многобройните случаи с метафорично значение не на отделни лексеми, а на фразеологизмите, в които те влизат (да направя някого на кайма; храна за размисъл), както и сложните названия.

Както е известно, метафоричното значение се поражда от контекста. Съответната лексема изтъква метафоричното си значение на преден план, когато се съчетава по значение със семантиката на друга лексема, която няма комбинаторните възможности, задавани от буквалното значение на първата лексема. В някои случаи под влияние на контекста дадена лексема може да има две и даже повече различни метафорични значения.

Сред анализираните случаи на метафорична употреба се откроиха следните 5 разновидности:

1. Със своята многобройност сред всички останали изпъква групата метафори, при които лексемата вместо буквалното си значение е изтъкнала на преден план съответното метафорично значение въз основа на прилика между същността на 
референтите в буквалната и в метафоричната ѝ употреба (на първичните и вторичните номинати). Например лексемата глад (в буквалното си значение изисква обект от областта на храните) в изрази като глад за знания / за работна ръка / за удоволствия и др. е употребена метафорично именно въз основа на прилика по същност, защото между буквалното значение на тази лексема: остра потребност от храна /.../ (БТР 2018), и значението на силна нужда от знания / работна ръка / удоволствия се набелязва именно същностна прилика (остра потребност = силна нужда). Трябва да се отбележи, че чувството на глад в езиковото съзнание на българина допуска и одушевяване / персонификация на подлога: напр. пазарът може да бъде живо същество: Пазарът изпитва глад за работна ръка. Близкото по значение съществително жажда от същата група показва по-ограничена възможност за метафорично свързване: не може да се припише на обект, който не е живо същество, по-точно не е човек, и затова не можем да кажем, че *Пазарът изпитва жажда за работна ръка. Затова пък съществителното жажда може да има като обекти повече понятия, отразяващи явления, от които човек може да има нужда - жажда за: знания / удоволствия / сън / почивка / любов / мъст и др. Този факт може да се обясни донякъде и с наличието на съответен глагол - жадувам, който се свързва без проблем в метафоричното си значение с посочените съществителни, срв.: жадувам за знания / удоволствия / сън / почивка / любов / мъст, което улеснява тази употреба и с отглаголното съществително, докато глаголът гладувам не се използва с непреки допълнения с предлога за (*гладувам за хляб / знания и т.н.). Струва ми се освен това, че преносното значение на глад е свързано с по-голям интензитет на нуждата в сравнение със значението на жажда, срв.: глад за знания > жажда за знания, което вероятно отразява подобно възприемане и при буквалните значения на двете съществителни: нуждата от храна е по-мъчителна от нуждата от вода и кара човека да се стреми по-активно към нейното удовлетворяване.

По подобен начин в значението на глагола изпивам (пия нещо докрай, изцяло БТР 2018) може да се открие елементът 'поемам нещо в себе си изцяло', който присъства и в метафорично употребения глагол изпивам някого с поглед. Разликата се състои в това, че буквално изпиваме с устата си, а метафорично - с очите си, и в това, че при буквалното изпиване обектът се пренася в нас, а при метафоричното става дума за обсебване на обекта, което остава в рамките на желаното.

Следващ пример от тази група е съществителното огризки, което в своето буквално значение: остатъци от нещо ядено, гризано (БТР 2018) съдържа и конотация, свързана с оценка за стойността на обекта като подчертано ниска. Такива същностни семантични елементи: остатъци и ниска стойност, се съдържат и в метафоричното 
значение на лексемата огризки в примери като следния: Те си разпределиха краденото, а за него оставиха огризките.

Обратно на това, в значението на лексемата каймак (жълтеникава маслена съставка, която се събира, натрупва като кожеста покривка по повърхността на варено мляко - БТР 2018) същностен семантичен признак е местонахождението на каймака на повърхността, т.е. в най-високата част на съда с мляко, както и конотацията за неговата високо оценявана хранителна стойност. Тези два семантични елемента пък отнасят разглежданата лексикална метафора към областта на ориентационната метафора на Лейкъф и Джонсън доброто е горе (Lakoff \& Johnson 2010: 44). Същите семантични елементи се запазват и при метафоричното значение, срв. изрази като каймакът на обществото, каймакът на нашия випуск и др.

Особен интерес представляват многобройните случаи на метафорична употреба на лексеми, свързани с вкусовите перцепции. Това са следните лексеми: безсолен, бонбон, вкисвам се, вкиснат, възкисел, горча, горчив, горчивина, горчилка, догорчава ми, докиселява ми, вгорчавам (живота на някого), заслаждам, ки́сел, киселичък, лют, меден, насолявам някого, разлютявам, разкиселявам се, разкисвам се, слади ми, сладникав, сладня, сладост, сладостен, сладък, сол (солта на живота), солен, услаждам се, шекерче, шербет. Прави впечатление, че петте основни вкусови усещания: за горчиво, кисело, сладко, солено и лютоㄱ, имат различни по брой възможности за метафорична употреба. Най-много лексеми се срещат от първите три вкуса, особено от областта на сладкия, който може да се съчетава с най-много обекти (срв.: сладко котенце, сладка свобода, сладникав роман; горчива истина, горчива чаша, вгорчавам живота на някого; вкисвам се, много съм кисел днес), като всяко от вкусовите усещания има сравнително еднообразно метафорично съответствие: горчивото се свързва със силно отрицателни емоции и мъка, сладкото (но не сладникавото) напротив - с приятни усещания и емоции, киселото - с намръщеност (както човек се мръщи, когато яде лимон) и отпуснатост. От значението на солен вкус метафорична употреба се среща само при лексемите солен / безсолен, сол и насолявам някого. При това соленият вкус може да се свърже със значение на висока степен на някакво качество, която не предизвиква особено приятни чувства: солена шега (остроумна шега, която обикновено е обидна), солена сметка (прекалено висока за някого), насолявам някого (с обилните си критични забележки будя у някого неприятни чувства). Липсата на сол обаче не води до обратните емоции - безсолен отново означава качество,

3 Лютивият вкус в литературата обикновено не се разглежда като основен, но на мен ми се струва, че той е достатъчно откроен в съзнанието ни. 
будещо отрицателно отношение (безсолен вищ). Това изглежда се обяснява с факта, че солта е, от една страна, необходима за човека (за разлика от захарта, киселината във формата на лимон, оцет и др. и свойството на горчивите храни), но от друга стойността ѝ варира в зависимост от количеството (насолявам означава не просто посолявам, а засипвам с прекалено много сол). Метафоричното значение на самата лексема сол се среща рядко, напр. в библейски контекст: солта на живота, където означава 'най-ценното, това, което запазва от развала', или в изрази като солта в разказаната история - отново в значение 'най-ценното'. Лютият вкус се среща в метафорична употреба преди всичко при прилагателното лют, където означава качество на даден обект да предизвиква болка със своята интензивност: люта рана, люта обида. В значението на съчетанието с лексемата ракия (люта ракия) може би силният градус на ракията се свързва с болка при нейното изпиване. В съотнасяне с лексемата рана метафорично се употребява и глаголът разлютявам (раната). Към лютия вкус може да се отнесе и метафоричната употреба на прилагателното пиперлив и на съществителното пиперлия: пиперлива шега (в значение на остроумна или на нецензурна шега) или пък пиперлия човек (който лесно избухва и се сърди). Освен тези пряко свързани с петте вкусови усещания лексеми, към тази група добавям и четири, които буквално означават по-неопределен вкус: блудкав, водникав (воднист), да разводня / разводнен, вода, а метафорично означават ниска стойност на обекта заради слабата изразеност или липсата в него на определени качества, срв. за метафоричното значение на вода при Е. Пернишка: 1) Ястие без добър вкус (Pernishka 1993: 232); 2) Многословие и бедност на мисълта в текст (Pernishka 1993: 139).

Малко по-особена семантична структура има лексемата вкус заедно с производната от нея лексема безвкусен както в своето буквално, така и в своето метафорично значение. В контекст с лексемата храна, характерен за буквалното значение на лексемата вкус, получената синтагма храна с вкус може да се определи като тавтологична (предполага се, че вкусът е иманентно качество на храната), а лексемата вкус има в нея като второ буквално значение 'качество на храна или друго вещество да предизвиква такова усещане' (има се предвид усещане за сладко, солено, горчиво и под., изтъкнато като първо буквално значение на тази лексема, БТР 2018). За да не бъде посочената погоре синтагма тавтология, към иманентното на храната свойство трябва да се добави конкретизиращо определение: храна с екзотичен вкус, храна с вкус на риба и др. Когато храната получи като определение производното прилагателно вкусна, възможно става само едно семантично тълкувание - приятен, будещ приятно усещане. Това значение не е производно пряко от значението на мотивиращото съществително вкус (който има вкус), а съдържа и конкретизиращ семантичен елемент 'будещ приятно 
усещане’. Под влияние на отрицателната семантика на представката / предлога без този семантичен елемент ('будещ приятно усещане’) изчезва, съответно при прилагателното безвкусен като определение на съществителното храна ще се разбира само че храната няма открояващ се вкус. Като обобщение, при буквалното значение на корена вкус- в съчетание с названието на някаква храна се очертават семантичните варианти: 1) вкусът, чието наличие е иманентно неконкретизирано качество - в тавтологични съчетания ( ${ }^{*}$ храна с вкус); 2) конкретизиран вкус като специфична особеност (храна с вкус на царевица); 3) вкус, специфициран като приятен (вкусна храна = храна с приятен вкус); 4) вкус, който се откроява чрез своята липса - в съчетание със знака минус, изразяван чрез предлога / представката без (безвкусна храна; храна без вкус).

За разлика от буквалното значение на лексемата вкус, което, както видяхме, включва два взаимодопълващи се елемента: усещане за качество на храната: солено, сладко и т.н. / качество на храната да предизвиква това усещане, метафоричното значение запазва само първия от посочените елементи: усещане за качеството на даден обект, при това съответното качество е постоянно: красота, изящество (в БТР 2018 метафоричното значение е дефинирано като усет за красиво, изящно). Затова в словосъчетанието човек с вкус лексемата вкус, употребена метафорично, означава точно това: човек, който има усет за красиво, изящно, и словосъчетанието не е тавтологично, защото наличието на такъв усет не е иманентно качество за човека по принцип. Тук обектът, към който се проявява усещането, няма възможност за вариране - усет за красивото и изящното, затова най-често лексемата вкус не се нуждае от определение (каквото би било напр. определението изискан). Понеже, както беше посочено по-горе (в 4), белязаното със знак минус значение на предлога / представката без откроява като специфична особеност на някакъв обект само липсата на вкус (т.е. няма зададени параметри на вкуса), няма пречка то да се свързва както с обекти от областта на храните и напитките, така и с обекти от метафоричната употреба на лексемата вкус и производните от нея лексеми (безвкусна храна ↔ безвкусни мебели, човек без вкус). Докато белязаното с плюс прилагателно вкусен, както видяхме в 3), има семантичен елемент 'приятен, будещ приятно усещане', който влиза в противоречие със семантичния елемент 'усет към красивото, изящното' (усетът не буди приятно усещане). Затова прилагателното вкусен има само буквално значение: вкусна храна (но не и ${ }^{*}$ вкусни мебели).

Към тази група спадат и някои явления, съпровождащи или предизвикани от яденето и пиенето. Например лексемата бълвоч буквално означава 'будеща отвращение повърната храна', но в контекст като напр. Възмути ме целият този ..., който чухме тази вечер на събранието значението ѝ се променя в метафорично и започва 
да означава будещи отвращение думи, т.е. нещо, което, както и храната, излиза от някого. Или на концерт: Не мога да слушам повече този бълвоч - будещата отвращение музика също се възприема като излизаща от изпълнителя. В контекст, свързан не със слушане, а с гледане, напр.: Какъв бълвоч беше тази изложба!, метафоричното значение ще може да се изрази като 'будещи отвращение картини' и пак ще се свързва с нещо, което излиза от своя творец. Така приликата по същност се състои в това, че обектът излиза по някакъв начин от някого и буди отвращение у субекта. Подобна е трансформацията и при глаголите повдига ми се (от нещо, от някого), повръща ми се (от нещо, от някого).

Като пример за подгрупата 'дейности, свързани с приготвянето на храната и напитките за консумация' може да бъде посочена лексемата втасал (съм). Буквалното ѝ значение се определя в БТР 2018 като: надигам се, бухвам под въздействието на мая, квас и ставам готов за печене, а от него при метафорична употреба остава най-същностното - ставам готов. Така в примера Вчера едва втасах да си прочета пощата метафоричното значение включва извършването на много други дейности, след които субектът е станал готов да извърши и е извършил и действието прочитам си пощата.

Глаголът със значение на приготвяне на храна (о)пека е застъпен в тази група най-напред във формата си на страдателно причастие, което изразява човешко качество, уподобено по своята същност на качеството на миналата през термична обработка храна: Той е много печен; Той е изпечен крадец. Възприеманото като общо за човека и храната качество изпеченост е резултат от възприеманото като общо по своята същност пребиваване в нажежена обстановка, т.е. при трудни условия (при храната - при термична обработка), която е развила у тях достатъчно висока степен на завършеност по някакви параметри (опитност за човека, пригодност за ядене за храната). В подобно значение се използва и самата глаголна форма в контекста на съществителното с пределно абстрактно значение работа в ролята на обект, напр.: Oneкох си работите, както трябва. Тук глаголът да опека придава по-голяма образност и същевременно конкретност в сравнение напр. с глагол с по-абстрактно значение, срв.: Уредих си работите, както трябва. Мотивационният признак на метафоризацията може да се определи като обща за двата номината по своята същност обработка на обекта (храна / някаква абстрактно възприемана дейност) до неговата пълна пригодност (неслучайно несвършеният вид на глагола тук не може да се употреби, срв.: *Пека си работите).

Към тази група спадат и много други лексеми, неспоменати досега: anemum, благина, гладник, глътка, десерт, дъвча някого, еликсир, жаден, завирам (от жега), 
за закуска (Той ме схруска злобно за закуска), залък (Това се оказа прекалено голям залък за мен), замесвам, засищам, изгълтвам (Изгълтах книгата наведнъж), изконсумирам (брака $\rightarrow$ термин), кокал, коктейл, откърмен (с песните) ${ }^{4}$, лапам, меден, меся, ненаситен, облизвам се (за нещо), опивам се, опиум, опиянение, опиянявам се, пиян, поглъщам някого/нещо, преглъщам (обидите), предвкусвам, предъвквам, пресищам се (на удоволствия), пържа се (на някакъв огън), схрусквам някого, сяждам някого, тесто (като термин: гипсово тесто), тлъст, утолявам (любопитството си), ядка (според БТР - най-хубавата, най-ценната част от нещо).

2. Значително по-малко лексеми включва следващата група - лексеми, при които метафоричният пренос се извършва на базата на някаква отделна обща черта, принадлежаща на референтите в буквална и в метафорична употреба на лексемата. Например при съществителното боза в изреченията Изпих една боза и Как можеш да слушаш тази боза? не можем да кажем, че същността като цяло на обекта боза в буквално и в метафорично значение е подобна или още по-малко, еднаква. Общото, което прави възможна метафоричната трансформация, е свойството и на двата обекта - мътна, неизбистрена структура. По сходен начин общата черта при сложното съществително тюрлюгювеч в буквална и в преносна употреба е безпорядък, при захаросан - изкуствено сладък, при каша - това, че обектът е свързан с бъркане (в метафоричната употреба - с бъркотия). Интересна е жаргонната метафорична употреба на съществителното кифла, която придава на лексемата значението отпусната, съгласна на всичко девойка. Разбира се, и тук не можем да търсим същностна прилика между двата обекта, но и общата черта се открива по-трудно. Може би това са характерните за такива девойки черти на липса на открояваща се специфика, податливост и мекост - черти, които в по-абстрактна перспектива могат да се видят и при кифлата като храна. Ако потърсим общата черта при действието кълва в буквално значение за птица - поемам храната си с човка, и в метафорично значение зубря (уча механично, усвоявам материала без разбиране, БТР 2018), ще я открием в тази негова особеност - без разбиране, т.е. без сдъвкване - както птицата яде с клюна си. Разликата между тази, втора, и първата група лексеми, за която стана дума по-горе, е понякога условна (както напр. и тук), защото зубренето и кълването могат да се представят и като еднотипен процес на поемане в себе си, усвояване на нещо, който се извършва без преработване, но по-важното в случая тук според мен е подобието именно по начина на извършване на съответните действия. Към тази група спада

4 Това причастие може да се възприеме и като метафора (песните са за някого като майчиното мляко), и като метонимия (откърмвам $\rightarrow$ отхранвам $\rightarrow$ отглеждам някого). 
и лексемата сухар, която има буквално значение специално приготвен или допълнително препечен, изсушен хляб, който трае дълго време (БТР 2018) и метафорично значение скучен, безинтересен и несърдечен човек (БТР 2018). Общата черта се крие в значението на прилагателното сух: буквално - който не съдържа влага (БТР 2018) и метафорично - който е лишен от любезност, сърдечност, чувство (БТР 2018). Съответствието между двете значения би могло да се обясни с метафоричното свързване на влагата със сълзите и с чувствата, с топлотата и живостта на сърцето. При C. Колковска откривам един от редките примери на метафоризация на дума от разглежданата сфера с резултат образуването на термин - сандвич ('конструктивен елемент в строителството') (Kolkovska 2012: 4), срв. по-горе и тесто (гипсово), както и да изконсумирам (брака), а също и бульон (хранителна среда - вж. по-долу).

В тази група също е представен глагол със значение приготвяне на храната глаголът да изпържа, срв. в примера: Изпържиха ме яко тези мошеници! Тук може да се предложи следното обяснение, което води до постигането на образност като причина за прибягване към метафоризацията: глаголът означава, че някой някого е излъгал много ловко. Като резултат от такъв личен неуспех потърпевшото лице изживява силно отрицателни чувства, които в една прототипна ситуация предизвикват зачервяване на лицето му. Според мен именно това зачервяване, което съпътства и пърженето на храната, е общата характерна черта, която се явява мотивационен признак на метафоризацията.

Друг пример за отделна характерна черта в ролята на мотивационен признак представлява и лексемата лига, чийто референт в буквалното ѝ значение се свърза с дейността на храносмилателната система: 1) гъста и обилна слюнка, 2) потекла, проточила се от устата слюнка (БТР 2018), и съдържа конотацията 'безформено, буди неприятни усещания'. В метафорична употреба съществителното запазва тази характерна конотация и в контекст, който подсказва, че става дума за човек, метафоричното ѝ значение става 'неприятно любезен, превзет или несполучливо духовит' (БТР 2018), където конотацията за безформеност се поддържа от неестественото поведение и отново се съчетава с буди неприятни усещания. Същата метафорична трансформация се извършва и при прилагателното лигав.

Към тази група съм включила и лексемите бульон (=хранителна среда; мотивационен признак ще бъде общата черта 'течност с хранителни вещества в нея'), канелен (очи), компот, мазен (мазна усмивка), миш-маш, мляскам някого (= целувам го шумно), ояждам се (на някаква служба), попара, тричав (тричава работа). Значението на всички лексеми (освен канелени (очи)) съдържа като конотация пренебрежително или иронично отношение на говорещия към обекта. 
3. Като разновидност на горната група може да се определи тази (трета) група, в която лексемите получават метафоричен прочит на базата на една фиксирана обща черта - общата форма. Например можем да чуем упрек към някой ученик, че тетрадката му е баница, и този метафоричен пренос се извършва на базата на изгледа на баницата и на разпарцаливената и мазна тетрадка. По подобен начин, на базата на кръглата форма с празно пространство по средата, могат да се свържат геврекът и воланът. Метафоричната употреба на кюфте се основава на сравнително малките размери и закръглен облик (Сuнът ù e едно кюфте). Метафорични значения на този принцип получават и лексемите баклавичка (ромбовидна форма - плат с десен на баклавички), зелник, мекица, палачинка, поничка, пръжка, тиквеник, при което всички те представляват видове храна, приготвена от човека (и по разбираеми причини са съществителни). Отново при почти всички (с изключение на неутралната лексема баклавичка) значението съдържа и конотация за пренебрежително или иронично отношение на говорещия към обекта. Интересен е случаят с лексемата тиквеник (Виж го тоя тиквеник къде кара!). Тук общата форма се долавя, ако обърнем внимание на мотивиращата дума тиква, която има преносно значение човешка глава; куфалница, кратуна (БТР 2018), т.е. тиквата се свързва с формата на човешка глава, която при това не е особено умна (аналогията тук идва от това, че по средата тиквата е куха, вж. и Pernishka 1993: 135). А вероятно метафоричният пренос при лексемата тиквеник се улеснява и от суфикса -ник, който иначе е характерен повече за лексемите със значение на човек и не толкова със значението на храна: мошеник, разбойник и т.н.

4. Много интересна е групата, събрала лексеми, към чието метафорично значение може да се приложи амбивалентно тълкуване - и от гледна точка на лексикалната метафора (каквато имахме досега), и от гледна точка на анализа на понятийната метафора. Тези лексеми са глаголи, при които метафоризацията се извършва на базата на подобие в същността на съответното действие в буквално и в метафорично значение на лексемата, т.е. спадат към първата разглеждана в статията група лексеми.

4.1. В голяма част от представените в тази точка случаи извършителят на действието е неодушевен обект, който може да се възприеме и метафорично. Тъй като разглежданите в статията глаголи от областта на храненето се свързват със субекти живи същества, при метафоричното им тълкуване тук ще става дума за персонификация или одушевяване на субекта (родова метафора според класификацията, представена в Ковечеш 2011: 196; бих определила общия ѝ модел като Х е човек / живо същество, който / което P). Такива са примерите: ближа (огнените езици ближат стените на къщата); задавям се (печката се задави); изпивам (болестта е изпила жената); 
изсмуквам (тъмната стая го е изсмукала); изяждам (страстта ми изяде ума); напива се (дъската се напива с вода и набъбва); пия (земята пие дъжда); поглъщам (войната погълна много средства; заниманията погълнаха вниманието ми); ям (ръждата яде желязото; угризенията ме ядат). По-горе вече посочих, че този вид метафори са свързващото звено между понятийните и лексикалните метафори. Ако се вземе за пример изречението Войната погълна много средства, към него може да се приложи гледната точка на компонентния анализ, която прилагах и досега - открояване на семантичните компоненти на буквалното и на метафоричното значение при дадена лексема и най-вече - на общата сема, която се открива и при двата вида значение. Тогава носител на метафоричното значение ще бъде лексемата поглъщам (погълна), която има буквално значение гълтам, поемам нещо изияло, гълтам определено количество; поемам, задържам в себе си (БТР 2018). Метафоричното значение ще се гради върху семата 'поемам и задържам в себе си определено количество от нещо' и така метафоричното тълкуване ще осигури в съответния контекст пълнотата на значението на изречението: Войната поема в себе си голямо количество средства.

Ако приложим обаче когнитивната гледна точка и открием в същото изречение понятийна метафора, тогава първата абстрактна същност - война - ще се възприема като живо същество, което поглъща като храна нещо, което е материално, а втората абстрактна същност - средствата - ще бъдат този материален обект храна, който живото същество поглъща. Тогава метафорично тълкувана ще бъде цялата ситуация. По същия начин ще се тълкуват и огнените езици, които ближат стените, и печката, която се задавя, и болестта, която е изпила силите на жената, и т.н.

В началото на статията стана дума за това, че в зависимост от контекста дадена лексема може да има повече от едно метафорично значение. Тук ще посоча като илюстрация разгледаната вече лексема изпивам: в т. 1. споменах метафоричната употреба на този глагол изпивам някого с поглед, където контекстът със значение на субект - одушевен извършител и обект - също одушевен, а най-вече - на извършване на действието с поглед, предизвиква метафоричен пренос въз основа на прилика в същността. В тази точка показвам друг вид метафоричен пренос при същия глагол - в контекст на подлог, заеман от абстрактно съществително с пропозиционално значение: Страстта му е изпила ума; Болестта го е изпила. Както видяхме, при анализа на това метафорично значение можем да подходим по два различни начина - като отделяме общия семантичен компонент на първичния и вторичния номинат, мотивационния признак на лексикалната метафора, изразена от глагола да изпия, или като представим цялата изразявана ситуация като понятийна метафора (страстта е живо същество, което пие ума на човека). По подобен начин ще се 
тълкува и глаголът със значение, изразяващо същото действие, но по отношение на храна - изяждам. Когато подлогът е абстрактно съществително с пропозиционално значение, срв.: Тези занимания ни изядоха иялото свободно време, наблюдаваме явлението, изложено вече при глагола да изпия. Любопитно е, че умът на човека за българина не се изяжда, а се изпива; обратно - времето се изяжда, а не се изпива, макар че в друга понятийна сфера тече. С глагола изяждам се свързват обекти като: главата (Тези амбиции му изядоха главата), времето; с глагола изпивам могат да се свържат: ума, силите, енергията, младостта. Формално тук подлогът може да бъде и човек или животно: Със своите глупости той ми изяде времето, но в действителност одушевеният извършител е само каузатор на съответното действие: Той направи глупости, които ми изядоха времето.

В примери като Това чувство ме ядеше все повече имаме подобна, амбивалентна разновидност на метафоричното значение, но с позиция на обект със значение на човек (срв. за същото и примера от по-горе: Болестта го беше изпила), което означава, че и човекът може да бъде възприеман в перспективата на понятийната метафора като храна или питие за някаква анимизирана или персонифицирана същност. Накрая, в изрази и с двата глагола от типа на: Те ми изядоха / изпиха париците ми се струва, че не става дума за метафора, а за метонимия, така че те не са обект на вниманието ми тук.

4.2. В първата точка от изложението си включих една доста голяма група глаголи за действие с извършител човек (или животно), при които метафоризацията се извършва на базата на подобие по същност. Повечето от тях, най-вече тези, които са преходни, могат според мен да получат на едно по-дълбоко ниво на възприемане и тълкуване от перспективата на понятийни метафори. Така например изразът предъвквам нещо може да се възприеме и като ситуация, при която мислите на субекта са ядивни същности, които той предъвква, срв.: Той все предъвква вариантите, но не се решава да предприеме нищо. По подобен начин и метафорично употребеният глагол преглъщам може да предположи и ситуация, в която обидите, които някой преглъща, представляват такива ядивни същности: Не можах да преглътна обидите . Срв. и други глаголи: засищам (Той не можеше да засити апетитите си), изгълтвам (Изгълтах романа за една нощ), лапам, облизвам се (за нещо), опивам се, опичам си работите, опиянявам се, поглъщам някого / нещо, предвкусвам, пресищам се (на удоволствия).

5. В една неголяма група лексеми коренът, който получава метафорично значение, участва в словообразувателен процес и по този начин фиксира своя контекст 
като единствено възможен (в състава на сложна или производна дума). Затова тук метафоричното значение се превръща в основно. Тези лексеми отново според мотивационния признак на метафоризацията могат да се отнесат към групата от т. 1, с уподобяване по същност между първичния и вторичния номинат. Такива са четири сложни прилагателни с първа част корен слад-, прави впечатление, че всички те са свързани със сетивото на слуха: сладкогласен, сладкодумен, сладкозвучен, сладкопоен. При тях първичен номинат е качеството 'сладост', на което при вторичния номинат се уподобява по същност (по предизвиквани усещания) абстрактното и трудно изразимо по друг начин качество на съответния издаван звук. В други две лексеми - съществителни - имаме характеристики на човек: сладур, изедник. Към тази група включвам и глагола самоизяждам се, който също има само метафорично значение заради задължителното насочване на действието изяждам към самия извършител. Като наблюдение може да се открои, че участници в тези деривати са или коренът слад-, или коренът изяждам / ям.

6. Отделила съм и две лексеми, заемки от турски език, при които нямам напълно убедително обяснение за основанието, върху което се извършва метафоричният пренос. При първата от тях - гювеч - по-често съществителното се използва като наречие за начин със значение безплатно: Давам ти това гювеч - взимай и не nuтаŭ! Другата лексема е съществителното тутманик. Докато при посочения погоре случай с тиквеник, както видяхме, може да се открие обща черта между първичния и вторичния номинат на тиква, която дава база за метафоричен пренос, тук може да се предположи фонетична причина - може би за ухото на българина първата сричка - mym, и то под ударение, е звучала грубо, което е правело думата подходяща за обидна квалификация, каквото е значението на тутманик.

И така, получените пет разновидности метафорична употреба на лексемите от сферата на храненето, които отделих в представените по-горе точки, могат да се сведат до две групи по характера на мотивационния признак: 1) подобие по същност; 2) подобие по отделна черта. На практика разновидностите от 4. и 5. точка спадат към първата група, а уподобяването по форма - към втората група. При лексемите от 4. точка прилагам като допълнителен критерий начина на тълкуване на семантиката (анализ по семантични компоненти или прилагане на понятийна метафора), а при лексемите от 5. точка - участие в словообразувателен модел (което превръща метафоричното значение в основно). На един следващ етап от анализа на разглежданите лексеми трябва да им се направи и класификация по семантични разновидности на мотивационния признак и на получените вторични номинати (семантикономинационни категории по Pernishka 1993). 
След извършената класификация и анализ на метафорите от областта на храненето в българския език ще се опитам да направя обобщение кои по-абстрактни същности и явления могат да се изразяват метафорично с лексеми от тази сфера на колективния опит на носителите на българския език. Откроиха се най-напред 1) различните видове емоции, усещания, страсти, настроения, физиологически състояния, по-често отрицателни (преглъщам обидите, вкисвам се, жадувам, изпивам с поглед, люта рана, завирам (от жега); 2) действия и явления, които будят емоции (дъвча / насолявам / схрусквам / изпържвам някого, вгорчавам живота на някого, горчива чаша, опиянявам някого, предвкусвам нещо), отново по-чести са отрицателните; 3) обекти на оценка (висока - каймакът на обществото; ниска: кълва си урока; боза); 4) отделни характеристики, които често са извън определена норма (солена шега, пиперлива забележка, еликсир); 5) дейности, свързани с ползване на облаги (лапам от държавната хазна, кокал, ояждам се).

По изключение лексеми от разглежданата област служат за образуване на термини - това са свързаните с вкусовите усещания лексеми киселини, захари, соли (при това граматически ограничени чрез свеждане само до форми за множествено число), както и отбелязаните лексеми бульон, сандвич, тесто (гипсово), консумирам (брака). Прави впечатление, че имената на напитки се срещат много по-рядко в метафорична употреба - такава имат само боза, вода, еликсир. Това се обяснява както с техния ограничен брой като цяло, така и с характерната им безформеност, която не допуска метафоризацията им по признака на прилика във формата.

В някаква степен чрез метафоричните употреби говорещият винаги осъществява свои прагматични цели. От наблюденията над метафорите от сферата на храненето се набелязаха три основни цели. Като първа причина за прибягване към метафорични употреби, свързана с говорещия, може да се изтъкне желанието му да направи речта си по-образна и картинна (земята пие дъжда; глад за удоволствия). Много рядко лексеми от разглежданата област се използват за по-конкретно изразяване на абстрактно понятие без стремеж към образност, който ми се струва главен при този вид номинация: замесвам, меся.

Най-често прагматична цел е и предаването на отношението на говорещия към обекта: отвращение (повръща ми се от него, тлъст, мазен, баница), обратно - умиление и симпатия (сладур, меден, бонбон), презрение (сухар, кифла, тиквеник, тутманик) и др. Понякога такава цел може да бъде скъсяване на дистанцията с някого чрез придаване разговорен характер на речта (втасвам, за десерт, гювеч).

Като цяло може да се обобщи, че метафоричната употреба на лексемите от областта на храненето показва връзката, която българското езиково съзнание установява 
между когнитивната област на храненето, от една страна, и когнитивната област на емоциите, усещанията, субективните състояния, от друга. При уподобяването на номинатите по форма целевата област включва конкретни предмети, но пак основни цели са постигането на образност и изразяването на отношение. Образността се постига по различни начини. В едни случаи и двата уподобявани обекта са конкретни (например при уподобяването по форма: тетрадка баница), в други случаи, от областта на т.нар. синестезия, т.е. на взаимодействието между сетивните възприятия, по-слабо конкретно възприятие се уподобява на възприятие с по-висока степен на конкретност, срв: сладък звук (вкусовото възприятие се възприема като по-конкретно и разпознаваемо в сравнение със слуховото); сладко коте (тук вкусовото възприятие предава още по-абстрактно възприятие - зрително, съчетано с предизвиквано субективно отношение). В трети случаи на конкретно, физиологично явление се уподобява абстрактно, субективно психологическо или емоционално състояние: жажда за знания; горчилката на живота (във втория пример вкусовото възприятие служи за предаване на когнитивно състояние, каквото е житейският опит). При групата на амбивалентно тълкуваните глаголи (страстта ми изпи ума), ако глаголът се анализира като лексикална метафора, тогава конкретното, физическо действие служи за предаване на абстрактно психологическо, емоционално или физиологично субективно състояние (изпивам водата $\rightarrow$ изпивам ума). Ако цялата изразявана ситуация се тълкува като понятийна метафора, чрез персонификацията или одушевяването (в цитирания пример - на страстта) не се извършва предаване на по-абстрактно чрез по-конкретно, защото еднакво абстрактна е страстта, възприемана както като неодушевена същност, така и като одушевено същество. Тук носителят на по-висока степен на нагледност и разбираемост е идеята за одушевеност и представата за одушевено същество, извършващо конкретни действия, общи за одушевените същества, включително и за човека.

Към основната си номинативна образна функция метафората от сферата на храненето по-често има добавена и прагматична функция: изразяване на оценка и/ или отношение на говорещия или стремеж към скъсяване на дистанцията със събеседника чрез придаване на по-разговорен характер на речта5. Затова използването на лексеми от анализираната сфера с терминологична функция е изключение.

5 В това отношение хетерогенна е групата на тълкуваните амбивалентно глаголи. Прагматична функция е придадена, ако обектът на действието е човек (болестта го е изпила). Ако обектът или субектът на действието е неодушевена същност (огнените езици ближеха стените на къщата; печката се задави), метафоричното значение изпълнява само основната функция - придаването на образност. 


\section{ИЗПОЛЗВАН ИЗТОЧНИК}

БТ Р 2018: Български тълковен речник. Четвърто издание. София: Наука и изкуство, 2018.

\section{БИБЛИОГРАФИЯ}

Dragichevich 2010: Dragichevich, Rayna. Lexicology of Serbian Language. Belgrade: Zavod za Udžbenike, 2010. [In Serbian: Драгићевић, Рајна. Лексикологија српског језика. Београд: Завод за уџбенике, 2010.]

Kolkovska 2012: Kolkovska, Sia. "New Metaphorical and Metonymical Meanings of Nouns in the Bulgarian Language.” Balgarski ezik, no 4 (2012): 17-27. [Колковска, Сия. „Нови метафорични и метонимични значения в българския език, възникнали при съществителните имена”, Български език, по 4 (2012): 17-27.]

Kolkovska 2013: Kolkovska, Sia. "New Metaphorical Meanings of Adjectives and Verbs in the Bulgarian Language." In Blagoeva, Diana \& Kolkovska, Sia et al., eds. Problems of Neology in Slavic Languages, 185-207. Sofia: AI Prof. Marin Drinov, 2013. [In Bulgarian: Колковска, Сия. „Нови метафорични значения в българския език, възникнали при прилагателни имена и глаголи.“ В: Проблеми на неологията в славянските езици, 185-207. Съст. и науч. ред. Д. Благоева, С. Колковска, М. Лишкова. София: АИ Проф. Марин Дринов, 2013.]

Kovecses 2011: Kovecses, Zoltan. Language, Mind and Culture. Krakow: Universitas, 2011. [In Polish: Kövecses, Zoltán. Język, umyst, kultura. Kraków: Universitas, 2011.]

Lakoff \& Johnson 2010: Lakoff, George \& Johnson, Mark. Metaphors We Live By. Warsaw: Aletheia, 2010. [In Polish: Lakoff, George \& Johnson, Mark. Metafory w naszym życiu. Tłum. Tomasz Krzeszowski. Warszawa: Aletheia, 2010.]

Pacheva-Karabova 2005: Pacheva-Karabova, Svetla. "Metaphorical Language of Contemporary Bulgarian Academic Medicine." PhD dissertation. Plovdiv: Medical Univesity, 2005. [In Bulgarian: Пачева-Карабова, Светла. „Метафоричният език на съвременната българска академична медицина.“ Докторска дисертация. Пловдив: Медицински университет, 2005.]

Pernishka 1993: Pernishka, Emiliya. On the Systematicity in the Lexical Polysemy of Nouns. Sofia: Bulgarian Academy of Sciences, 1993. [In Bulgarian: Пернишка, Емилия. За системността в лексикалната многозначност на съществителните имена. София: БАН, 1993.]

Stancheva 2015: Stancheva, Zhana. "Bulgarian and Polish Folk Names of Diseases (From Names of Plants and Animals).” In Cholakova, Zhorzheta\& Chakarova, Juliana et al., eds. Slavistics - Paths and Prospects, 171-179. Plovdiv, Paisii Hilendarski University Press, 2015. [In Bulgarian: Станчева, Жана. „Български и полски народни названия на болести (мотивирани от названия на 
растения и животни)". В: Чолакова, Жоржета \& Чакърова, Юлиана и кол., ред. Славистиката - пътища и перспективи. Сб. в чест на 7о-годишния юбилей на проф. д.ф.н. Иванка Гугуланова, 171-179. Пловдив, УИ Паисий Хилендарски, 2015.]

Vershinina 2002: Vershinina, Tatyana. "Zoomorphic, phytomorphic and anthropomorphic metafors in contemporary political discourse." DSc thesis. Yekaterinburg: Ural State Pedagogical University, 2002. [In Russian: Вершинина, Татьяна. „Зооморфная, фитоморфная и антропоморфная метафора в современном политическом дискурсе.“ Диссертация на соискание ученой степени кандидат филологических наук. Екатеринбург: Уральский государственный педагогический университет, 2002.] 